\begin{tabular}{|c|c|c|}
\hline 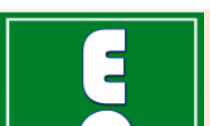 & $\begin{array}{l}\text { International Journal of Current Research in } \\
\text { Biosciences and Plant Biology }\end{array}$ & 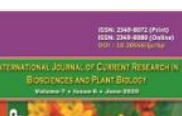 \\
\hline & Volume 7 • Number 6 (June-2020) • ISSN: 2349-8080 (Online) & 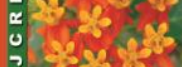 \\
\hline $\begin{array}{l}\text { EXCELLENT } \\
\text { PUBLISHERS }\end{array}$ & Journal homepage: $\underline{\text { www.ijcrbp.com }}$ & \\
\hline
\end{tabular}

\title{
Intense selective logging of Populus deltoides Bartr. amid novel Covid-19 and its subsequent edge effects and forest fragmentation: An alarming scenario in the plant ecology of Kashmir Valley
}

\author{
Muzafar Riyaz, S. Ignacimuthu², S.M. Zuber3* ${ }^{*}$ \\ ${ }^{1}$ Division of Biodiversity, Entomology Research Institute, Loyola College, Chennai - 600 034, Tamil Nadu, India \\ ${ }^{2}$ Xavier Research Foundation, St. Xavier's College, Palayamkottai - 600 072, Tamil Nadu, India \\ 3Department of Zoology, Government Degree College, Bijbehara, Anantnag, Kashmir - 192 124, India \\ *Corresponding author; e-mail: zubairhuma@gmail.com
}

\begin{tabular}{|c|c|}
\hline Arti & ABSTRACT \\
\hline $\begin{array}{l}\text { Date } \\
23 \mathrm{M}\end{array}$ & \multirow{8}{*}{$\begin{array}{l}\text { In the Kashmir Valley, Populus deltoides is the most favored tree species used for } \\
\text { plantation. The Poplar tree species are considered as economical backbone of farmers } \\
\text { in Kashmir since they were introduced by Department of Social Forestry in 1984. These } \\
\text { plant species have become an important low-cost timber option for Kashmiri farmers } \\
\text { and generate livelihood for thousands in the region. The poplars are wind pollinated } \\
\text { and the fruits ripen from end of May to early June. Ripe fruits release small seeds which } \\
\text { have a mass of long, silky hairs to aid their dispersal by wind. These silky hairs are } \\
\text { scattered in the air and cause some allergic reactions in some individuals of Kashmir } \\
\text { leading to wheezing and hacking in April and May. On April 10, } 2020 \text { the High Court of } \\
\text { Jammu and Kashmir issued stay order on cutting of the poplars keeping in view the } \\
\text { spread of Covid-19 infection. Over the past fortnight people had already employed } \\
\text { laborers and a large scale of Poplar trees were unearthed. The mass cutting of these tree } \\
\text { species will have numerous ecological and financial implications. }\end{array}$} \\
\hline & \\
\hline Кеy & \\
\hline & \\
\hline & \\
\hline & \\
\hline & \\
\hline & \\
\hline
\end{tabular}

\section{Introduction}

Populus deltoides belongs to the family Salicaceae; it is a cotton poplar. It has been regionally misreported as Russian Poplar (Russi Phress) as Populus deltoides is native to North America. The clones of Populus deltoids (Singh et al., 2001) were introduced in Kashmir in the year 1984 (Table 1). They adapted well to the local climate (Temp range $-10^{\circ}$ to $38^{\circ} \mathrm{C}$ ). It is the only fast-growing tree species in Kashmir Valley. The blossoms show up in spring season when trees are as yet leafless and both the sexes stay on independent trees which can develop to 30-40 feet in height. The ripe fruits release small seeds, which have a mass of long, silky hairs to aid their dispersal by wind. Seed production in poplar starts when the trees are 5 to 10 years old, expanding quickly in sum as the trees become older and bigger. Yearly seed production gauge of a solitary open-developed tree has been assessed as high as 48 million seeds. Over 15.22 million trees of poplars under distinctive diameter class with complete assessed volume of 5.29 million cubic meters are planted across Kashmir (Mir et al., 2017) and around 90 percent of the volume acknowledged from poplars is acquired 
from the domain of Populus deltoides. These clones had been effectively incorporated in lots of land use structures and are currently spread in each corner of the Valley. The wood is utilized for material rafters and making cases to ship important agricultural produce like apples, pear and peaches other than its utility in the plywood industry. During the months of May, June and July these seeds are scattered in the air as cotton flakes. These have brought about some health hazards in Kashmir valley. The silky hairs from the seeds cause respiratory issues; however no rigorous study has been performed to back the case and no link has been established with Covid-19 infection.

Table 1. Clones of Populus deltoides Bartr. introduced in Kashmir.

\begin{tabular}{llll}
\hline Clone & $\begin{array}{l}\text { Origin } \\
\text { Country/State }\end{array}$ & $\begin{array}{l}\text { Source country of } \\
\text { clone }\end{array}$ & Sex \\
\hline G48 & $\begin{array}{l}\text { Brazos } \\
\text { Texas }\end{array}$ & Australia & $\mathrm{F}$ \\
D75 & $\begin{array}{l}\text { Issaquena } \\
\text { Mississippi }\end{array}$ & USA & M \\
D121 & $\begin{array}{l}\text { Washington } \\
\text { Mississippi } \\
\text { Coahoma } \\
\text { Mississippi }\end{array}$ & USA & $\mathrm{F}$ \\
D171 & $\begin{array}{l}\text { Issaquena } \\
\text { Mississippi } \\
\text { Braz }\end{array}$ & USA & F \\
G3 & $\begin{array}{l}\text { Texas } \\
\text { Issaquena }\end{array}$ & USA & M \\
D67 & $\begin{array}{l}\text { Mississippi } \\
\text { State Forest Dept. }\end{array}$ & Australia & $\mathrm{M}$ \\
L-34/82 & $\begin{array}{l}\text { Haldwani } \\
\text { State Forest Dept. }\end{array}$ & GSA & M G3 \\
D161 & $\begin{array}{l}\text { Haldwani } \\
\text { State Forest Dept. } \\
\text { Haldwani }\end{array}$ & USA & $\mathrm{F}$ \\
D181 & USA & $\mathrm{F}$ \\
\hline
\end{tabular}

(Source: Singh et al., 2001).

\section{Role of Populus trees and consequences of large-scale axing}

The Populus species were introduced in Kashmir as a World Bank-aided social forestry scheme to boost the local economy by generating paid employment for the rural poor and to improve environmental conditions through plantations that provide fuel wood, small timber and meet the need for afforestation. The tree has become a part of Kashmir's landscape since then. In Kashmir Valley, the local apple box manufacturing units, mostly in Shopian, Anantnag and Kulgam districts are heavily dependent on these trees as these poplar trees meet $80 \%$ demand of fruit boxes \& 14 to15\% of raw material in ply board industry (Gangoo, 2015).Since inception of the project in 1982 until 2011, a total of 2805 lakh plants were planted over an area of 1.6 lakh hectares; besides 1568 lakh plants were distributed to the farmers (Digest of Forest Statistics, J \& K Forest Deptt-2011). A total of 4373 lakh Poplar plants have been raised by Social Forestry Department only other than the Private Nurseries/Growers. They have multi benefits like revenue generation, carbon sequestration, phytoremediation, uses in fruit industry, ecological waste water treatment systems, stream bank stabilization, soil building, biofiltration, and soil erosion control. Although these benefits are there the female trees produce seeds with silky hairs which cause some respiratory infections among people and children. In the wake of novel COVID-19 spread and before the onset of flowering season, the female Poplar trees had to be felled down in order to get rid of the menace of the pollens and silky hairs. The department, which had already felled 26,000 such 
trees in the past, issued an advisory to start a mass chopping of the tree species (Pervaiz, 2020). Over the time, an estimated number of over 5 lakh tree species were cut in the districts viz, Shopian (Fig. 1), Kulgam (Fig. 2), Pulwama, Anantnag, Srinagar, Budgam, Kupwara, Baramulla, Ganderbal and Budgam. The proposed mass tree felling will lead to an excess of supply and will lower prices for the final product in the coming harvesting season. In the future, there would be a shortage of trees, which will have an effect on the fruit growers as well. This will also result in targeting and deforestation of the other plant species like Ulmus, Salix alba, Acacia etc. and will lead to forest fragmentation since there will be no option left for the farmers and timber industry.

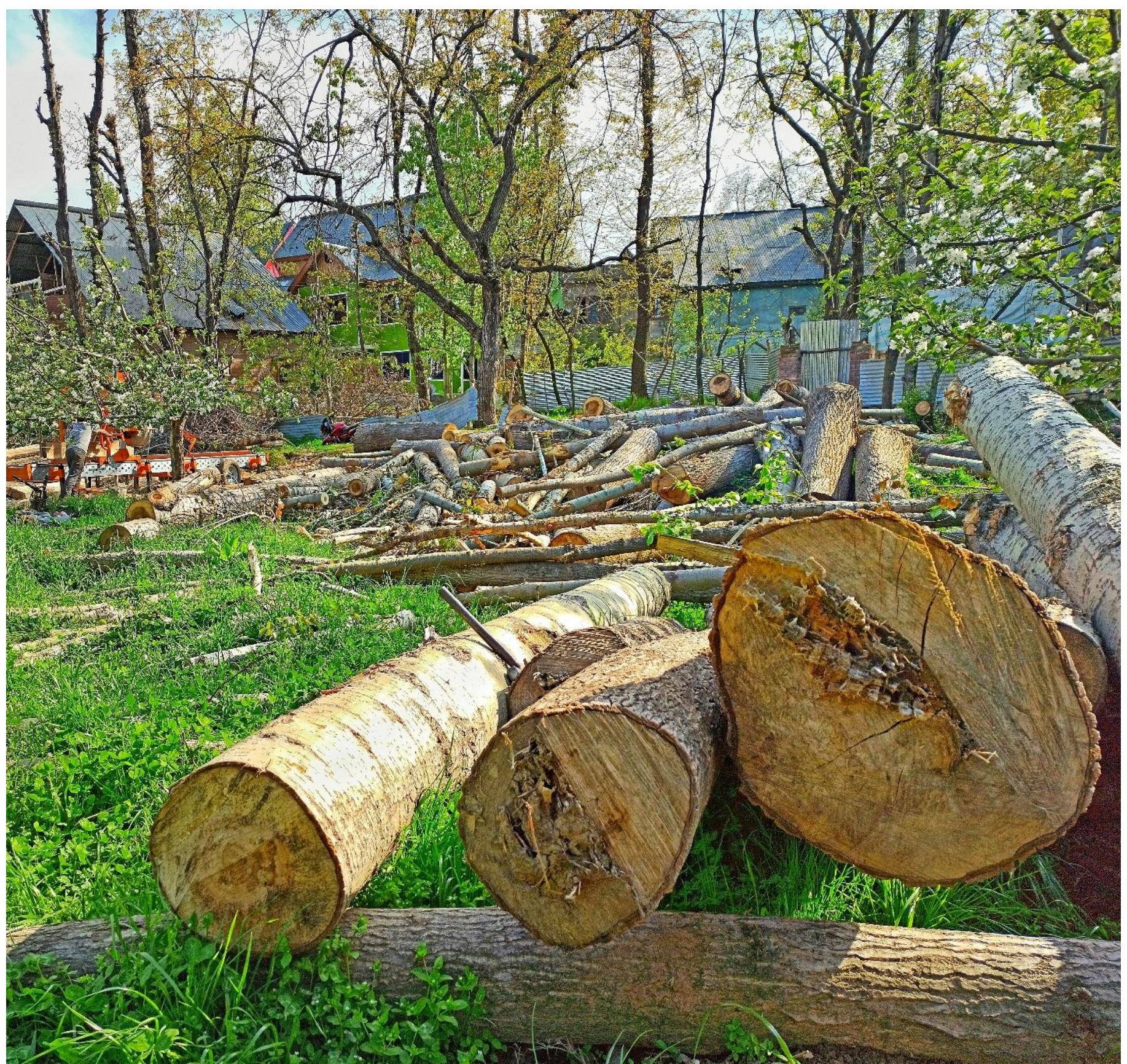

Fig. 1: Large Scale Axing of Populus deltoides near Herman, District Shopian, Kashmir (Photo: Muzafar RiyazApril 2020). 


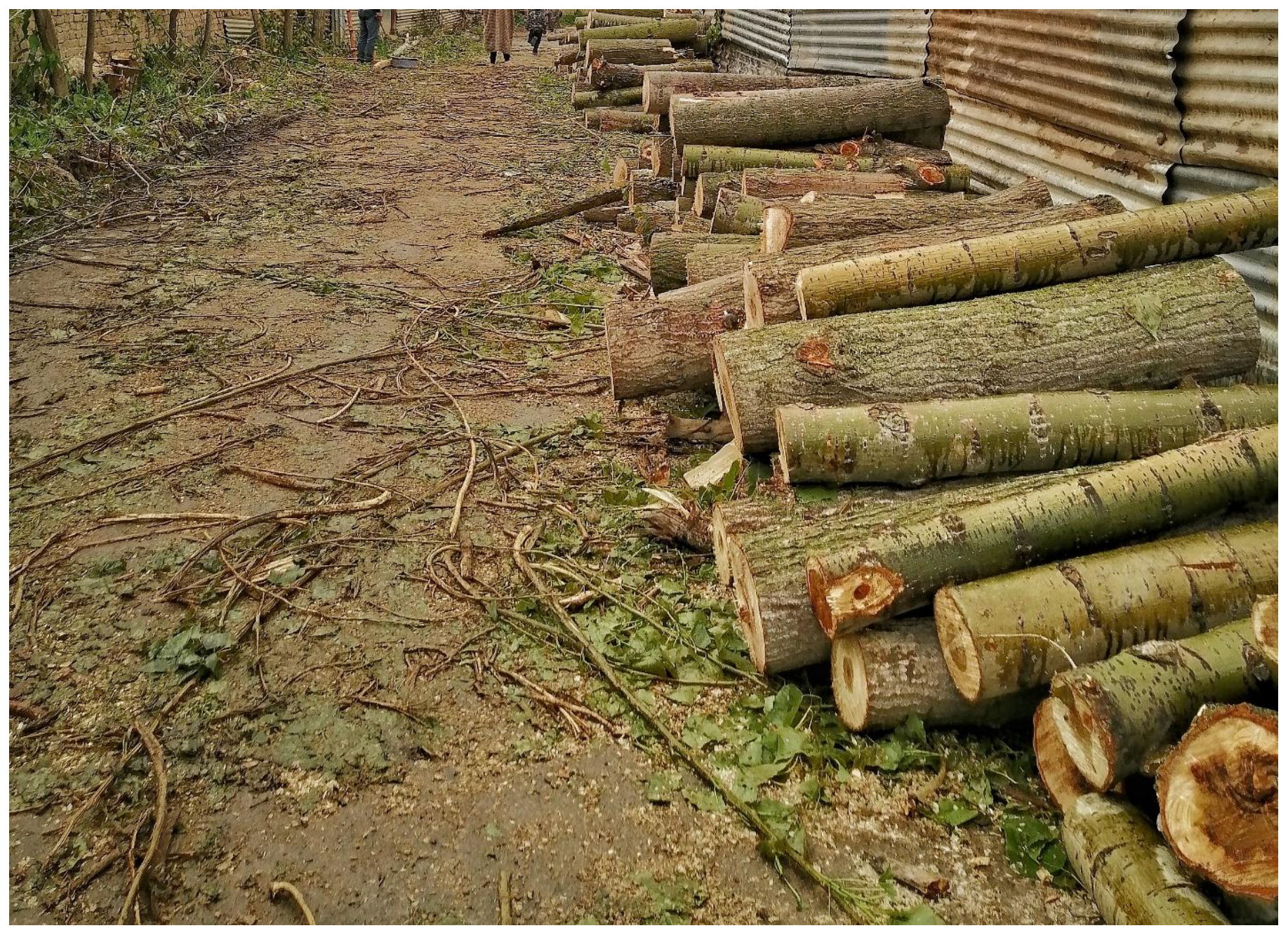

Fig. 2: Populus deltoides unearthed in large scale near Tungduno, District Kulgam, Kashmir (Photo: Muzafar RiyazApril 2020).

\section{Discussion and Conclusion}

In terms of environmental cleaning and economical value, the importance of poplar trees cannot be underestimated. Besides orchardists and farmers, people living near the banks of the River Jhelum are also dependent on these trees. The wood is also sought by pencil and plywood manufacturers outside Kashmir and this demand is making it a profitable venture. Over 30 plywood factories, registered with the Directorate of Industries and Commerce, depend on wood from these trees. To reduce the silky hair menace, it was hypothesized that reducing the number of branches by pruning will reduce the seed production by trees. It is feasible that simple pruning is enough to deal with the pollen shed by these trees. Pruning of poplar trees not only reduces the annoying silky hairs produced by the tree, but it also increases its productivity in terms of tree girth and height. The upper branches of the trees produce more seeds and therefore more silky hairs than the lower branches, so chopping could help in minimizing the dispersal quantum. Government Poplar growing departments, Farmers and poplar growers may be advised to cut down the upper and middle branches before fruit formation during the month of February/March. People sensitive to seed pollen allergies should use mask when exposed to the silky hairs during the month of April- May (generally for 15-30 days) when seeds are shed. They should avoid going to places where there are poplar trees growing in mass scale. The silky hairs may be collected and destroyed by burning or burying under controlled conditions, so that it does not spread and become a fire hazard. 
The areas around habitations and agriculture fields need to be kept clean. Mass plantation of female poplar trees within the urban areas / habitations is the real problem. Identifying female poplars after proper survey in the month of March- April when they start flowering, and subsequently removing of the female trees in a phased manner over a period of time will help to curb this menace. Once again it is reiterated that proper monitoring is essential till the trees become reproductive. The problem can be redressed by planting only male poplar clones for plantation purposes. Improved male clones of poplar suitable to the local conditions can be identified for future plantations. The government forest departments especially Social Forestry Department, after identification and verification of male and female trees, should release appropriate ratio of male and female poplar clones to maintain a balance in sex ratio of poplars while going for mass cultivation and distribution of plants to the farmers and growers.

There is a need for awareness creation and educating people for growing poplars in balanced ratio of male and female varieties so that in future we may not experience profuse pollen/silky hairs in the air beyond its carrying capacity. Above all there is an urgent need to develop better clones in future that will take care of every aspect related to Poplar Plantation including silky hair dispersal. Cutting of all the trees at once will result in an ecological catastrophe leading to economic collapse overnight.

\section{Conflict of interest statement}

Authors declare that they have no conflict of interest.

\section{Acknowledgement}

The authors wish to thank the Entomology Research Institute, Loyola College Chennai - 34, Tamil Nadu, India for extending necessary support and guidance.

\section{References}

Digest of Forest Statistics, J\&K Forest Deptt-201. https://tinyurl.com/ydegcfcl

Gangoo, S. A., Masoodi, T. H., Murtaza, S., Islam, M. A., 2015. Management of exotic poplars for production of quality timber and reducing cotton menace in Kashmir ( $\mathrm{J} \& \mathrm{~K}$ ). Indian Forester, 141(5), 514-519.

Mir, A. A., Masoodi, T. H., Mir, N. A., Rather, T. A., Sofi, P. A., 2017. Nursery performance of male clones of poplar (Populus deltoides Bartr.) under temperate conditions of Kashmir Valley. Curr. J. Appl. Sci. Technol. 21(1), 1-8.

Parvaiz, A., 2020. Coronavirus bane for thousands of poplar trees in Kashmir. https://www.nature asia.com/en/nindia/article/10.1038/nindia.20 20.63

Singh, N. B., Kumar, D., Rawat, G. S., Gupta, R. K., 2001. Establishment of breeding orchard of Populus deltoides Bartr. Indian Forester, 127(1), 3-10.

\section{How to cite this article:}

Riyaz, M., Ignacimuthu, S., Zuber, S.M., 2020. Intense selective logging of Populus deltoides Bartr. amid novel Covid-19 and its subsequent edge effects and forest fragmentation: An alarming scenario in the plant ecology of Kashmir Valley. Int. J. Curr. Res. Biosci. Plant Biol. 7(6), 64-68.

doi: https://doi.org/10.20546/ijcrbp.2020.706.007 